\title{
Planulation periodicity, settlement preferences and growth of two deep-sea octocorals from the northwest Atlantic
}

\author{
Zhao Sun ${ }^{1}$, Jean-François Hamel $^{2}$, Annie Mercier ${ }^{1, *}$ \\ ${ }^{1}$ Ocean Sciences Centre (OSC), Memorial University, St. John's, Newfoundland and Labrador, A1C 5S7, Canada \\ ${ }^{2}$ Society for the Exploration and Valuing of the Environment (SEVE), 21 Phils Hill Road, Portugal Cove-St. Philips, \\ Newfoundland and Labrador, A1M 2B7, Canada
}

\begin{abstract}
Adaptations and life history strategies have rarely been studied in deep-sea corals. Here we present laboratory data on the timing of larval release, reproductive output, substratum selectivity and growth of 2 alcyonaceans (Cnidaria, Octocorallia) from the bathyal zone of eastern Canada. Planulation patterns in 2 Drifa species were significantly influenced by seasonal productivity and the lunar cycle, and larval output was greater in larger colonies (from shallower depths). After release, planulae of Drifa sp. shifted their buoyancy to move between the bottom and the water column, whereas planulae of $D$. glomerata were largely demersal and crawled on the substratum until settlement (typically occurring after 1 to $30 \mathrm{~d}$ in both species). Settlement trials showed that planulae settled more readily on rough natural surfaces covered with biofilm than all other substrata tested and that larvae of colonies from deeper habitats were less selective than those originating from shallower habitats. In both species, the 8 primary mesenteries (and tentacle buds) appeared within 24 h post settlement, and polyps reached a maximum size after 2 to 3 mo. The first branching polyp was observed after ca. 9 mo of growth in D. glomerata, whereas no direct evidence of branching was detected in Drifa sp. over 21 mo of observation, although 2- and 4-polyp colonies were later discovered in the holding tank with adults. Together, these findings highlight dual traits of resilience (i.e. extended breeding period, long-lived larvae) and vulnerability (i.e. substratum selectivity, slow growth) in deep-sea corals.
\end{abstract}

KEY WORDS: Deep-sea $\cdot$ Corals $\cdot$ Reproduction $\cdot$ Brooding $\cdot$ Settlement $\cdot$ Growth $\cdot$ Drifa

\section{INTRODUCTION}

Deep-sea corals are important constituents of marine ecosystems (Buhl-Mortensen \& Mortensen 2005, Costello et al. 2005). Although there is increasing concern over their destruction worldwide (Roberts et al. 2006, Miller et al. 2009), research on the reproductive biology of deep-water and cold-water corals remains scarce. Determining reproductive output, recruitment and growth of deep-sea corals is crucial in assessing their regeneration potential in the context of deep ocean management. To date, most of the limited information has focused on hexacorals in the order Sclerac- tinia (Waller 2005, Waller \& Tyler 2005, Waller et al. 2005, Flint et al. 2007) and a few octocorals in the order Pennatulacea (Eckelbarger et al. 1998, Pires et al. 2009), whereas little attention has been given to soft corals (Alcyonacea) (Cordes et al. 2001, Sun et al. 2009, 2010), despite their prevalence and importance in deep-sea habitats (Freiwald et al. 2004, Watling \& Auster 2005). Reproduction in octocorals has mainly been investigated in shallow-water Alcyoniidae, Xeniidae, and Gorgoniidae from the tropical Pacific, Red Sea, and the Caribbean (Benayahu 1991, Shlesinger et al. 1998). Comparatively little research has been conducted on the reproduction and development of 
the widely distributed Nephtheidae (Farrant 1986, Benayahu et al. 1992, Dahan \& Benayahu 1997, Hwang \& Song 2007, Sun 2009, Sun et al. 2009, 2010).

The production and release of offspring is the initial step in a suite of processes that allows populations of benthic invertebrates to be replenished and maintained. Sexual modes of reproduction in corals include broadcast-spawning and brooding. In the deep ocean (below $200 \mathrm{~m}$ ), broadcasting appears to be the dominant trait, and reports of brooding species are rare (Cordes et al. 2001, Waller et al. 2008, Sun 2009, Sun et al. 2009, 2010). However, investigations of reproductive patterns in deep-sea corals are fraught with difficulty, and knowledge about these remains embryonic at best. Studies of shallow-water corals have shown that they may undergo synchronous or asynchronous spawning, seasonal or so-called continuous reproduction, and lunar or shifted lunar spawnings, and that their patterns of sexual reproduction could be correlated to several factors, such as temperature, depth, and tidal, lunar and solar cycles (Jokiel \& Guinther 1978, Stimson 1978, Benayahu \& Loya 1983, 1984, Benayahu 1997, Ben-David-Zaslow et al. 1999).

After release, larvae must recruit through settlement and metamorphosis. Settlement in benthic marine invertebrates is defined as the stage during which larvae leave the water column and come into definitive contact with the substratum, while metamorphosis is the physiological and morphological transformation into the juvenile stage (Rodriguez et al. 1993). Chemical or biological cues are usually essential to induce settlement. For instance, crustose coralline algae and bacteria have been shown to induce metamorphosis and selection of suitable habitats in reef corals (Heyward \& Negri 1999, Baird et al. 2003, Harrington et al. 2004). Environmental factors, such as seawater temperature, depth, current, physical texture and orientation of substrata also influence time to settlement and metamorphosis (Atoda 1951, Jokiel \& Guinther 1978, Hodgson 1985, Rogers 1990, Abelson 1997, Fabricius 1997, Heyward \& Negri 1999, Baird et al. 2003, Harrington et al. 2004).

Post-settlement growth is tied to recruitment (Rodriguez et al. 1993), which is essential in the maintenance and recovery of any ecosystem, including coral reefs (Glassom et al. 2006). The type of larva and its competency period are important indications of the probability of local recruitment and long-range dispersal (Richmond 1987). Brooders that release planulae which are ready to settle within the parental habitat are typically less dispersive than broadcasters (Sebens 1983a,b, Harrison \& Wallace 1990, Richmond \& Hunter 1990). While limited dispersal ensures that planulae settle within appropriate habitats and are helpful in maintaining the locally adapted populations, it decreases colonizing ability (Sebens 1983b) and affects population genetic structure (Ayre \& Miller 2004). As for planula release, the bulk of the knowledge on settlement preferences and post-settlement growth was gathered from shallow-water tropical corals. Substrate selectivity has never been examined in deep-sea corals, given the difficulties associated with maintaining and reproducing live animals in the laboratory and conducting in situ investigations.

The present study focused on 2 deep-sea nephtheids, Drifa sp. (as yet unidentified) and D. glomerata, with the goal of examining various aspects of their life histories and expanding our understanding of deepwater coral biology. By using histological procedures for light and electron microscopy and monitoring live specimens for over a year in the laboratory, we elucidated planulation periodicities, planula behaviour and substratum selectivity, as well as early juvenile growth. In addition, preliminary correlations were made with the environmental factors that are most likely to influence planulation, larval competency periods and recruitment rates.

\section{MATERIALS AND METHODS}

Field observation, collection and maintenance of adult colonies. Live colonies of Drifa glomerata and Drifa sp. were collected in July 2007 off insular Newfoundland at depths between 350 and $1240 \mathrm{~m}$ (Table 1) using the remotely operated vehicle (ROV) ROPOS from the CCGS 'Hudson'. While they possess slightly different sclerites, the 2 species can best be distinguished by the presence of specialized reproductive polyps in Drifa sp. (Sun et al. 2009). Twentysix Drifa sp. colonies and 2 D. glomerata carefully collected with their original substratum (to decrease stress and damage) were reared at the Ocean Sciences Centre. Holding tanks at ambient pressure were provided with running unfiltered seawater (ca. $1.51 \mathrm{~min}^{-1}$, pumped from the same general body of water in which the corals were collected) providing phytoplankton, zooplankton and resulting detritic material that were likely compatible with those of the native habitat. Conspecific colonies from the same depths were reared together in $20 \mathrm{l}$ tanks in dark conditions, the number of colonies per tank varying from 2 to 8 depending on the size of the colonies and of their attached substrata. Seawater temperatures fluctuated between -0.5 and $8.5^{\circ} \mathrm{C}$ over the course of the study (Fig. 1), following an annual cycle that closely matched the temperatures registered at 600 to $800 \mathrm{~m}$ along the Newfoundland continental slope (Stein 2007). An in-line chilling system was used during the warmest months. 
Table 1. Depth and coordinates of sampling sites for Drifa sp. (1 to 4) and D. glomerata (5 to 6) in July 2007. All colonies were kept alive except where otherwise mentioned

\begin{tabular}{|c|c|c|c|c|c|}
\hline Sampling sites & Depth (m) & Latitude $(\mathrm{N})$ & Longitude (W) & Number of colonies & Notes \\
\hline 1 & 495 & $44^{\circ} 58^{\prime} 36^{\prime \prime}$ & $54^{\circ} 58^{\prime} 51^{\prime \prime}$ & 1 & For histology and extraction \\
\hline 2 & 526 & $44^{\circ} 49^{\prime} 18^{\prime \prime}$ & $54^{\circ} 28^{\prime} 23^{\prime \prime}$ & 10 & Two for histology and extraction \\
\hline 3 & 744 & $44^{\circ} 49^{\prime} 45^{\prime \prime}$ & $55^{\circ} 33^{\prime} 41^{\prime \prime}$ & 2 & All for histology and extraction \\
\hline 4 & 1238 & $44^{\circ} 13^{\prime} 04^{\prime \prime}$ & $53^{\circ} 07^{\prime} 14^{\prime \prime}$ & 13 & Two for histology and extraction \\
\hline 5 & 358 & $44^{\circ} 21^{\prime} 38^{\prime \prime}$ & $53^{\circ} 15^{\prime} 57^{\prime \prime}$ & 1 & \\
\hline 6 & 358 & $44^{\circ} 21^{\prime} 38^{\prime \prime}$ & $53^{\circ} 15^{\prime} 58^{\prime \prime}$ & 1 & \\
\hline
\end{tabular}

Still images and video footage collected with the ROV were summarily analyzed to evaluate typical substrata utilization, orientation and aggregation of soft coral colonies. Particular attention was given to images and videos captured at depths of ca. 500 and $1200 \mathrm{~m}$ in areas where the live specimens were collected.

Collection and culture of planulae. Daily monitoring of reproductive behaviour in adult colonies extended from July 2007 to June 2008. Planulae of both Drifa species were routinely collected upon release or within $24 \mathrm{~h}$ post release, either on the bottom of the tank or in the water column. The planulae were reared in culture plates in semi-static conditions with half the seawater changed every day until settlement, 1 to $98 \mathrm{~d}$ post release. Some individuals were used for settlement preference trials as detailed below. Newly settled primary polyps were maintained under flow-through conditions similar to those described for adult colonies and fed a mixture of green algae (Tetraselmis suecica and Isochrysis sp.), brown algae (Nannochloropsis oculata) and rotifers on a continuous basis via a peristaltic pump (ca. $40 \mathrm{ml} \mathrm{min}^{-1}$ ).

In addition, planulae of Drifa sp. were surgically extracted from 7 colonies to determine whether natural release was a prerequisite to successful development through settlement, and whether surgical extraction would affect planula behaviour and metamorphosis. Colony size ranged from 2.3 to $4.0 \mathrm{~cm}$ in length and 1.5 to $2.5 \mathrm{~cm}$ in width when extended. The reproductive polyps were cut open, and planulae were gently pushed out into the surrounding seawater. Extracted planulae were cultured in $50 \mathrm{ml}$ beakers at a density of ca. 30 ind. beaker ${ }^{-1}$ under the previously described conditions. Cultures were monitored daily to record larval behaviour, the occurrence of settlement, and subsequent growth in order to compare patterns with those observed after natural release.

Environmental factors. Information on seawater temperature in the laboratory during the rearing and experimental period was gathered using a temperature-light logger HOBO Pendant (UA-002-64) placed in one of the holding tanks. As an indication of productivity and load of suspended matter in the water, the thickness of detritic matter accumulating in 3 Petri dishes placed on the bottom of the laboratory tanks was measured at regular intervals to calculate monthly average deposition rates. Additional data were obtained on average chlorophyll concentration (fluorescence units) in the top $30 \mathrm{~m}$ of the water column at Stn 27 from August 2007 to July 2008 through the Atlantic Zone Monitoring Program (Fisheries and Oceans Canada). Data collected from this station are representative of ocean conditions occurring over the Newfoundland shelf (Petrie et al. 1988) and correspond to the general characteristics of the water supplied to the laboratory (Gotceitas et al. 1999). Data on lunar phases were obtained from the StarDate Online website (http://stardate.org/nightsky/moon/).

Histology and microscopy. To determine the precise arrangement of gametes within the various sections of the branchlets and polyps, subsamples of colonies of Drifa sp. were processed using standard histological procedures (Sun 2009). A similar analysis of Drifa glomerata was performed on serially collected samples in the course of a previous study (Sun et al. 2010).

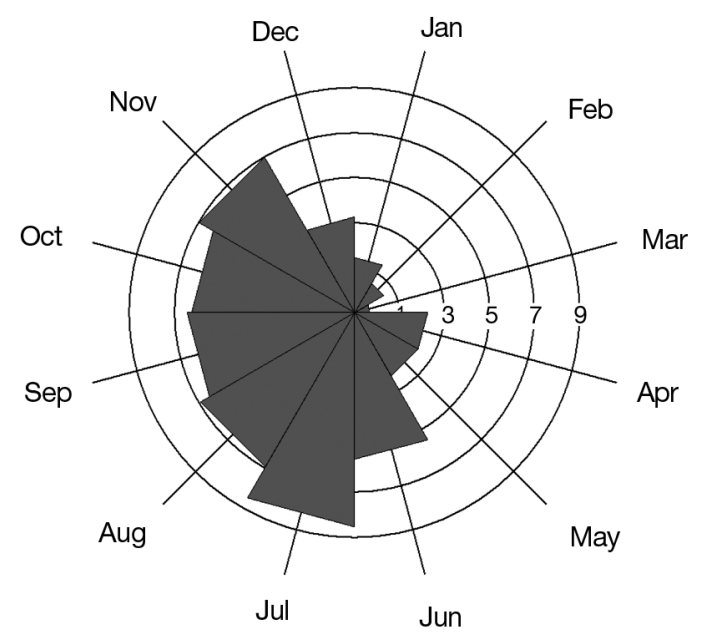

Fig. 1. Average monthly seawater temperature $\left({ }^{\circ} \mathrm{C}\right)$ from August 2007 to July 2008 
To gain a better understanding of fine larval structures and compare the maturity of planulae of various sizes, a few planulae of Drifa sp. were collected and fixed in $3 \%$ glutaraldehyde for processing using transmission electron microscopy (TEM) techniques. Tissues were embedded in polymerized blocks, sectioned $(0.5 \mu \mathrm{m})$ and stained with $1 \%$ toluidine blue in $1 \%$ aqueous sodium borate. Light microscopy observations were made under a Nikon Eclipse 80i microscope attached to a Nikon DXM1200F digital camera.

Settlement preferences. In both Drifa species, naturally released planulae were studied in order to determine substratum preferences and time to settlement and metamorphosis on different substrata.

In Drifa sp., planulae released at approximately the same time by colonies from similar depths were pooled together and used to test the following independent treatments: (1) NP: naturally conditioned culture plates (i.e. placed in running seawater for at least $7 \mathrm{~d}$ to allow a biofilm to develop); (2) NS: conditioned culture plates with shell fragments; (3) NPS: conditioned culture plates that had been sanded to create an irregular surface; (4) CS: culture plates with shell fragments that were cleaned in freshwater every day (to destroy any biofilm); (5) CP: culture plates which were cleaned in freshwater every day. Each condition was tested using 1 to 9 planulae at a time and replicated independently as many times as possible, depending on the availability of significant batches of planulae (from 3 to 21 times); the total number of planulae exposed to each treatment varied between 8 and 75. The planulae were released haphazardly in the experimental vessels, which were kept in dark conditions and positioned randomly in the holding tank used to maintain temperature stable throughout the trials. These general procedures apply to all trials unless otherwise mentioned.

To further investigate the settlement preferences and assess whether the larvae exhibit any substratum selectivity, pair-wise experiments were performed in which different types of substrata were tested against each other, including natural versus artificial substrata, rough versus smooth surfaces, and naturally conditioned versus clean surfaces. More precisely, 3 pairs of substrata were tested, as permitted by the limited number of planulae available, typically using 12 to 27 planulae for each trial, for a total of 4 to 8 replicates per condition: (1) NS (natural shell fragments) versus NPS (sanded and conditioned Petri dishes): the surface area of shells covered half the surface area of the Petri dish; (2) R (rough) versus S (smooth) surface: half the side of a Petri dish was sanded, then conditioned in running seawater for several days prior to use; (3) N (naturally conditioned) versus C (cleaned) surface: conditioned Petri dish with half the surface cleaned every other day (prior to use, each Petri dish was conditioned in running seawater for several days, and half its surface was cleaned every day). Planulae were monitored daily for $1 \mathrm{mo}$ to record the time to settlement and the number of settled planulae on each substratum. Pairwise experiments were performed only with the more selective planulae of colonies from $500 \mathrm{~m}$, owing to the limited number of planulae released by colonies from $1200 \mathrm{~m}$.

Planulation in Drifa glomerata occurred in a single colony. The limited numbers of naturally released planulae were used to perform only 3 pair-wise trials. The first 2 treatments are the same as for Drifa sp.: (1) NS (natural shell fragments) versus NPS (sanded and conditioned Petri dish surface); (2) R (rough) versus $\mathrm{S}$ (smooth) surface. However, in the third treatment with $\mathrm{N}$ (naturally conditioned) versus $\mathrm{C}$ (clean) surface, the Petri dishes were sanded prior to use, on the basis of a preliminary indication of a preference for rough substrata. The number of planulae tested for each trial varied from 12 to 27 , with 4 to 8 replicates per condition.

Statistical analyses. Circular statistics were performed using the software Oriana 3.0 (Kovach Computing Services) to detect monthly and lunar patterns. For the latter, dates were transformed into lunar days from 0 to 29, where 0 represents the new moon, and converted into angles (using 29.5 as the lunar period). Circular-linear regressions were used to test for significant relationships between the daily number of planulae released and the month of the year or the lunar period. Periodic regressions have been demonstrated to be among the most robust methods for detecting lunar periodicities in marine ecology (DeBruyn \& Meeuwig 2001). The null hypothesis that occurrences of planulation events would be equally or randomly spaced throughout the year or the lunar cycle was also tested using Rao's spacing test.

The generalized linear model procedure (GENMOD) of SAS (SAS 1988) was used to analyse planula settlement preferences. In Drifa sp., proportional data were tested using logistic regression (binomial distribution, logit link): logistic regression was used in the analysis of data from independent treatments to test the influences of depth range (500 $\mathrm{m}$ or $1200 \mathrm{~m}$ ) and substratum categories (NP, NS, NPS, CS, CP) on the proportion of settled planulae, and regression models were used to test the same factors on time to settlement in settled planulae. In addition, logistic regression was used in the analysis of data from pair-wise treatments to test the influence of different substratum types (NS versus NPS, R versus $\mathrm{S}, \mathrm{N}$ versus $\mathrm{C}$ ) on the proportion of settled planulae of Drifa sp. and D. glomerata. For all statistical analyses, residuals were examined to evaluate the assumptions of homogeneity, independence and 


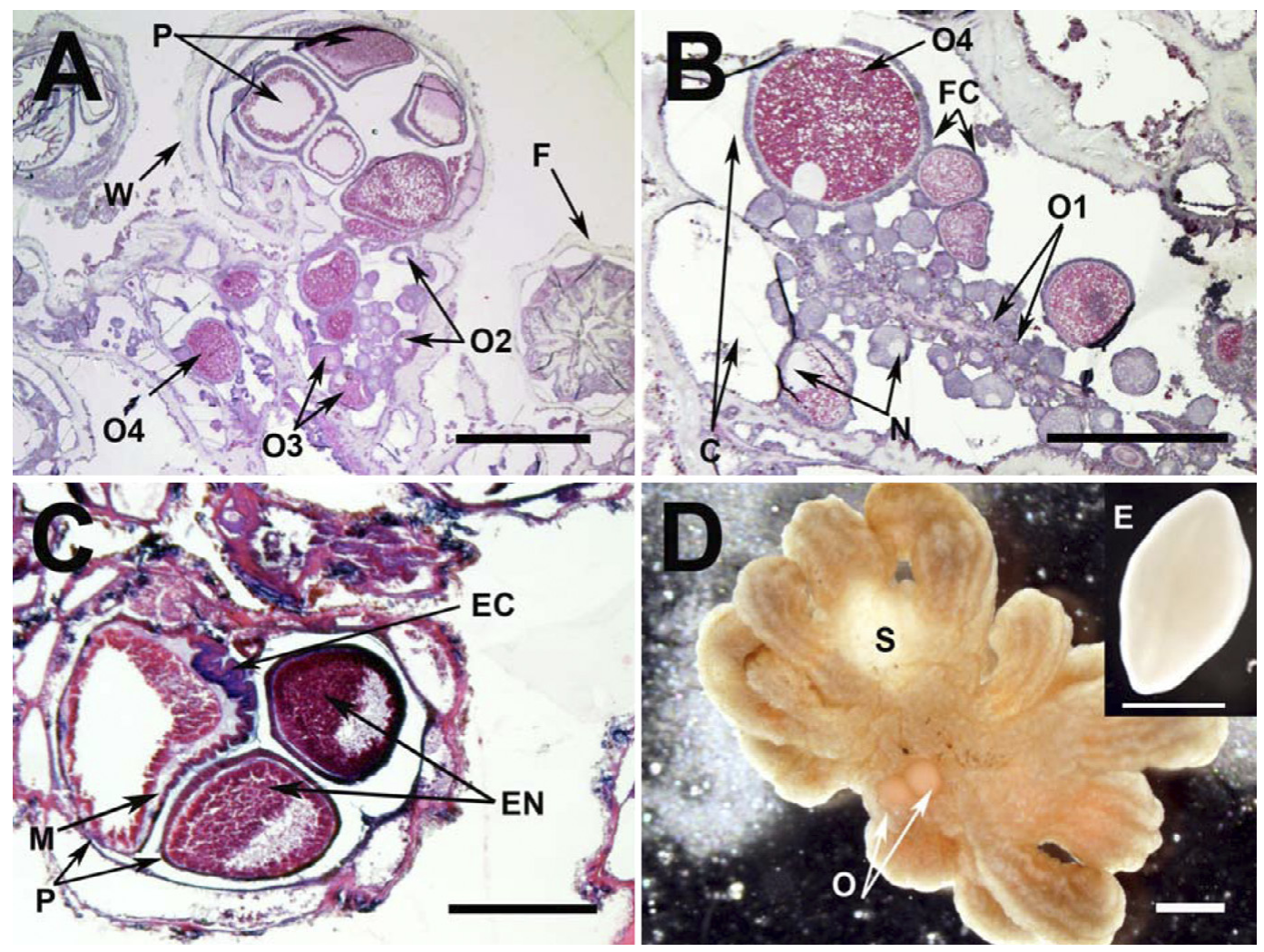

Fig. 2. Drifa sp. (A) Micrograph showing the spatial organization of gametes and planulae inside reproductive polyps. (B) Micrograph showing stages of oocyte development. (C) Well-developed planula within 1 reproductive polyp. (D) Branch with visible male and female gametes with close-up on a surgically extracted spermary in (E). F: feeding polyp; W: reproductive polyp wall; P: planula; O1: Stage I oocyte; O2: Stage II oocyte; O3: Stage III oocyte; O4: Stage IV oocyte; C: coelenteron; FC: follicle cells, N: nucleus; EC: ectoderm; M: mesoglea; EN: endoderm; O: oocytes; S: spermary. Scale bars = (A) $0.5 \mathrm{~mm}$, (B-E) $1 \mathrm{~mm}$

normality. Interactions were tested when there were enough degrees of freedom, and normal distribution and identity link were used unless otherwise stated. If a normal error distribution was not appropriate, gamma or Poisson error distributions were used (McCullagh \& Nelder 1989). Tolerance of Type I error was set at $\alpha=0.05$.

\section{RESULTS}

\section{Information from the field}

At depths shallower than $500 \mathrm{~m}$, most colonies of both species occurred on cobbles, rocks or rocky cliffs, both oriented horizontally and vertically. At $1200 \mathrm{~m}$, the substratum was primarily mud, with very limited occurrences of cobbles or rock surfaces. Colonies of Drifa sp. were sparse on mud and occurred in clusters (aggregated distribution) where appropriate hard substrata were available, such as bedrock, isolated rocks, pebbles, sponges, empty shells, tube worms, etc.

\section{Reproductive features}

In Drifa sp., oocytes and planulae are pinkish in colour (Fig. 2A-C), whereas male sexual organs (spermaries, Fig. 2D) are white. As per Cordes et al. (2001), oocytes were divided into 4 stages: Stage I, oogonia budding from the mesenteries; Stage II, previtellogenic oocytes containing a large nucleus; Stage III, vitellogenic oocytes, characterized by the rapid accumulation of yolk; Stage IV, late vitellogenic oocytes that are mature and filled with yolk droplets, which stain a conspicuous pink colour. Oocytes from Stages I to IV and planulae were observed simultaneously within a single reproductive polyp (Fig. 2A-C). The largest vitellogenic oocytes were $490.1 \pm 23.8 \mu \mathrm{m}$, and no embryos were observed in any of the colonies examined. Planulae were found only in what appear to be specialized reproductive polyps that do not possess tentacles for feeding and are shaped like a trunk (Sun 2009, Sun et al. 2009 for details). Data from live colonies of Drifa sp. showed that polyps containing planulae and/or gametes were present throughout the 
year under laboratory conditions. The presence of 1 spermary (ca. $2 \mathrm{~mm}$ ) was observed in 2 different colonies in December 2007 (Fig. 2D).

Drifa glomerata is also an internal brooder. Female sexual cells and planulae are pinkish in colour. The early stages of female gametes are attached to or embedded in the mesenteries, develop into planulae and are retained in fertile polyps (Sun 2009, Sun et al. 2010 for details). In D. glomerata, no specialized reproductive polyps were observed, the development occurring directly in feeding polyps.

\section{Planula release and behaviour}

\section{Drifa sp.}

The size at sexual maturity is fairly small: even the smallest colonies collected from $500 \mathrm{~m}$ (ca. 12 polyps, extended size ca. $3 \times 2 \times 2 \mathrm{~cm}$ ) and $1200 \mathrm{~m}$ (ca. 25 polyps, extended size ca. $3 \times 1 \times 1 \mathrm{~cm}$ ) were fertile (i.e. contained planulae).
The first planula release in Drifa sp. was observed in August 2007. Large colonies (i.e. extended colony size during spawning season ca. $11 \times 7 \times 7 \mathrm{~cm}$ ) were observed to release some planulae on a continuous basis from August 2007 to June 2008; however, planulation in several smaller colonies did not last as long, and 1 small colony (extended size ca. $3 \times 2 \times 2 \mathrm{~cm}$ ) was observed to be totally spent in November 2007 after ca. 8 wk of spawning.

Overall, there was no obvious diel trend in the timing of planula release, which occurred at any time of the day or night. Adult colonies could release more than 1 planula at the same time, generally from different polyps. On rare occasions when 2 planulae were released from the same polyp simultaneously, 1 exited through the opening while the other was released through a tear in the polyp wall.

On average, fully extended large planulae were 3 to $5 \mathrm{~mm}$ long and $1 \mathrm{~mm}$ wide; they were rod-shaped and covered with cilia. Planulae of Drifa sp. could adjust their position in the water column (between demersal and pelagic habitat) by contraction and expansion of
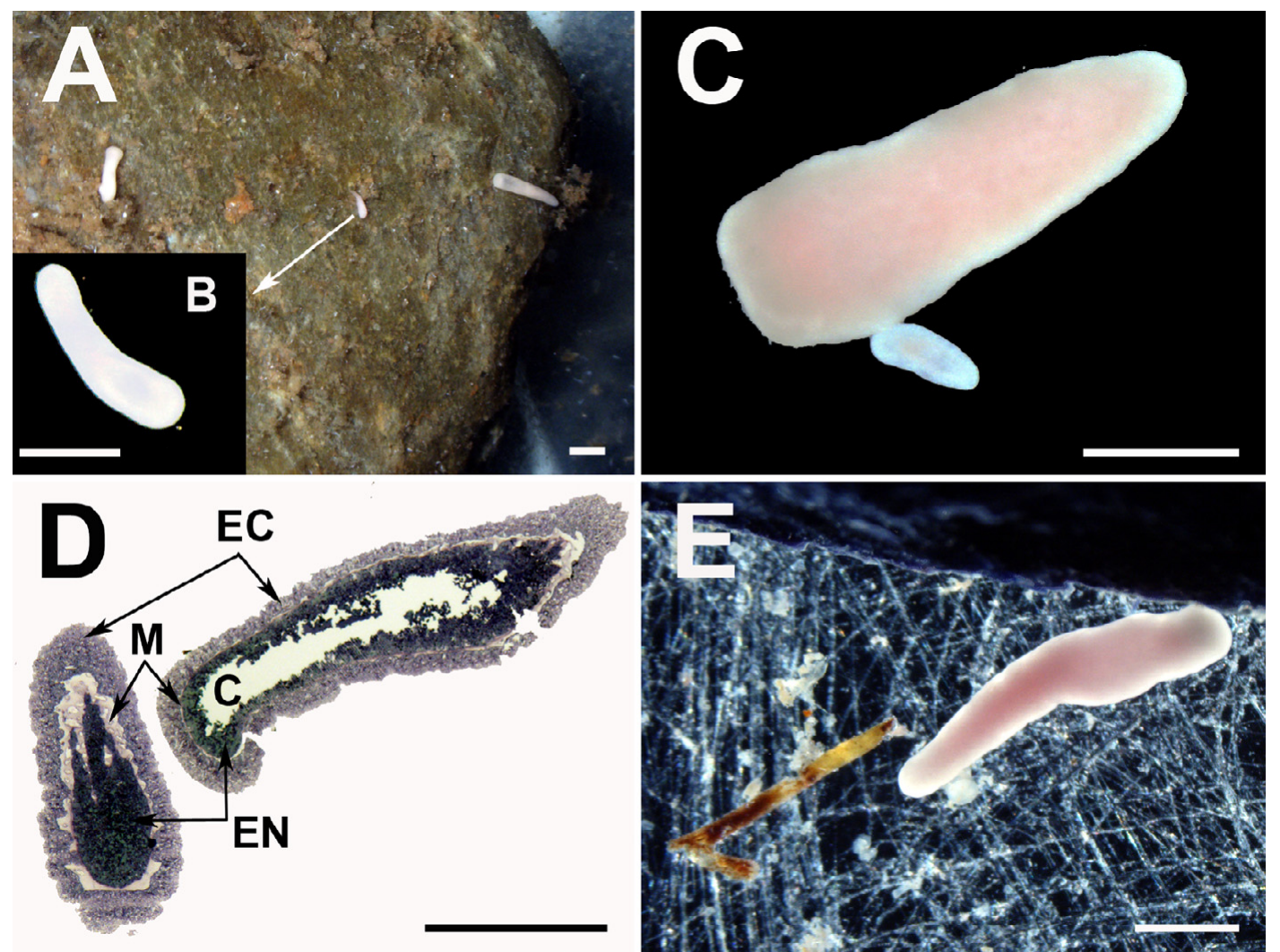

Fig. 3. Drifa spp. (A) Drifa sp. Newly released planulae of various sizes and (B) close-up on a small planula. (C) Drifa sp. Planulae of different sizes (0.05 vs $1.81 \mathrm{~mm}^{3}$ ), released simultaneously. (D) Drifa sp. Micrograph of sectioned planulae. (E) Drifa glomerata. Planula searching for adequate substratum for settlement. EC: ectoderm; M: mesoglea; EN: endoderm; C: gastrovascular cavity. Scale bars $=(A-D) 0.5 \mathrm{~mm},(E) 1 \mathrm{~mm}$ 
their whole body. Planulae probed the substratum with their aboral extremity; they used the oral extremity as an anchor to position the aboral extremity for attachment. A few smaller planulae (ca. 1 to $2 \mathrm{~mm}$ long) were observed to be released from reproductive polyps in colonies from $500 \mathrm{~m}$ (Fig. 3A-C). They were of similar shape and developed endoderm, mesoglea and ectoderm like the larger planulae (Fig. 3D). However, smaller planulae were not as prone to extend and contract. Some even smaller planulae $(<1 \mathrm{~mm})$ were also observed (Fig. 3B,C), but they were too rare to be studied in more detail.

\section{Drifa glomerata}

Planulation was observed in a single colony from January to June 2008. The average length of fully extended planulae was ca. 4 to $5 \mathrm{~mm}$, and the maximum length recorded was ca. 5.5 to $6 \mathrm{~mm}$ (Fig. 3E). Planulae were released from the mouth of feeding polyps. As was seen in Drifa sp., the adult colony of Drifa glomerata was extended during planulation. The colony released up to 3 planulae at a time from different polyps. Planulae were demersal, uniformly covered with ciliae and moved with their aboral extremity forward (Fig. 3E). Immediately after release, the planulae exhibited complex crawling behaviours; they were able to climb onto a shell and to circle vertically or horizontally by contracting and expanding rapidly, i.e. changing from fully contracted to fully elongated within a couple of minutes.

\section{Patterns of planula release}

\section{Drifa sp.}

From August 2007 to June 2008, 113 planulae were released by 11 colonies collected at $1200 \mathrm{~m}$ (although 2 colonies did not possess any discernable reproductive polyp, and 1 colony had a single reproductive polyp filled with planulae). On the other hand, 289 planulae were released by 7 colonies from $500 \mathrm{~m}$ (one colony contained fewer than 10 planulae-bearing reproductive polyps, and 2 colonies died in February 2008). The number of planulae released in a single day varied from 1 to 14 in the colonies from $500 \mathrm{~m}$, and from 1 to 5 in the colonies from $1200 \mathrm{~m}$.

On an annual basis, the relationship between number of planulae released and month of the year was significant for colonies from both depths according to circular-linear regression $(\mathrm{r}=0.158, \mathrm{p}<0.001, \mathrm{n}=434)$. Planulae were predominantly released between September and December, with a weaker secondary peak in March for colonies from 500 m (Fig. 4). The fall planulation peak that occurred in colonies from both depth ranges followed a rise in chlorophyll concentration in seawater (i.e. values increasing over 6 -fold between July and September) and coincided with high deposition rates of detritic matter in the tanks (Fig. 5). A second weaker planulation peak was observed the following spring in colonies from $500 \mathrm{~m}$. Its onset again coincided with a noticeable increase in chlorophyll concentration (i.e. spring bloom) and another peak in monthly deposition rates (Figs. 4 \& 5). No clear relationship was found between planulation events and seawater temperature (Fig. 1).

At a finer scale, the number of planulae released was significantly correlated with the lunar cycle $(\mathrm{r}=$ 0.245, $\mathrm{p}<0.001, \mathrm{n}=434$ ), with more planulae being released between the full and new moons than during the other half of the cycle in colonies from both depths (Fig. 4). Similarly, occurrences of planulation events irrespective of their importance $(\geq 1$ planula) followed a clear lunar pattern as well, both for pooled data and separate depth ranges (Rao's test, $U=280$, $\mathrm{p}<0.01, \mathrm{n}=135)$. The planulation events largely occurred between the full and last quarter moon and secondarily between the last quarter and the new moon, whereas they remained rare throughout the other half of the cycle, between the new and full moons (Fig. 4). When considering only major planulation events ( $\geq 3$ planulae), the lunar periodicity was evidenced in colonies from $500 \mathrm{~m}(U=203, \mathrm{p}<0.01$, $\mathrm{n}=53)$, but not in colonies from $1200 \mathrm{~m}(U=136, \mathrm{p}>$ $0.05, \mathrm{n}=19)$.

\section{Drifa glomerata}

Planulation lasted through June 2008, with a total of 74 planulae released by the single colony (Sun 2009, Sun et al. 2010 for more details on release patterns and the role of environmental factors). Because of the limited data available, statistical analyses could not be conducted on this species.

\section{Metamorphosis and post-metamorphic growth}

$$
\text { Drifa sp. }
$$

Metamorphosis generally coincided with settlement; however, a few planulae (ca. 10) exhibited partial metamorphosis or developed into polyps without settling on any substratum. These polyps either settled later or remained free in the water column during the whole experiment $(21 \mathrm{mo})$. When settling, the freeswimming planulae actively probed and then attached 
to the substratum. They then became cone-shaped (Fig. 6A) or flattened and underwent metamorphosis, developing 8 tentacles buds within $24 \mathrm{~h}$ post settlement. Primary polyps developed 8 tentacles with small pinnules (Fig. 6B). At 2 to 3 mo post settlement, polyps reached a maximum size of ca. 3 to $5 \mathrm{~mm}$ in length, with a stalk diameter of ca. $1 \mathrm{~mm}$. No further growth or budding of primary polyps was observed over 21 mo of
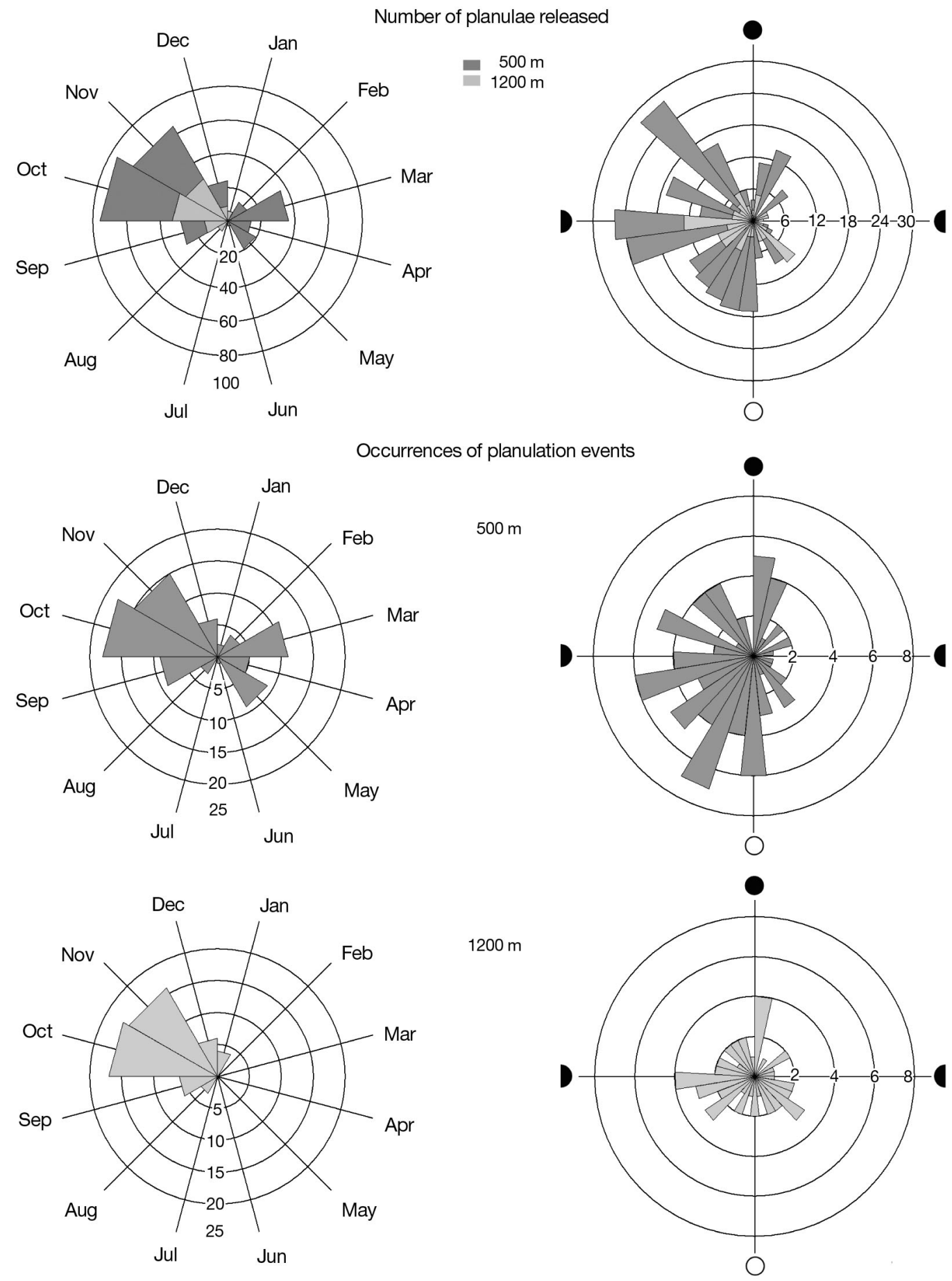

Fig. 4. Drifa sp. Circular plots showing the number of planulae released and the number of planulation events relative to the annual (left) and lunar (right) cycles. Data were collected in colonies from 2 different depths (500 and $1200 \mathrm{~m}$ ) between August 2007 and June 2008. Filled circle: new moon; open circle: full moon 
observation in the culture vessels. However, 2- and 4polyp unmonitored colonies were observed in holding tanks on substrata harbouring the adult colonies (Fig. 6C,D).

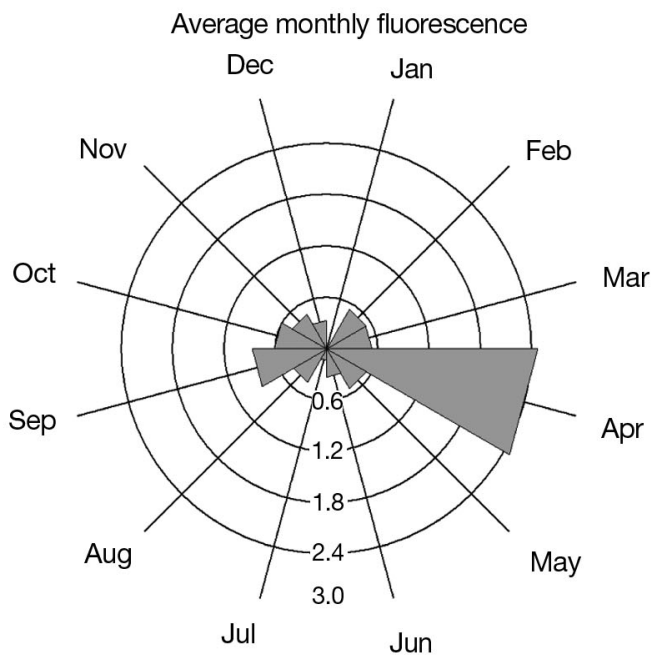

\section{Drifa glomerata}

Planulae of Drifa glomerata exhibited similar searching behaviour, settlement and metamorphosis (Fig. 7)

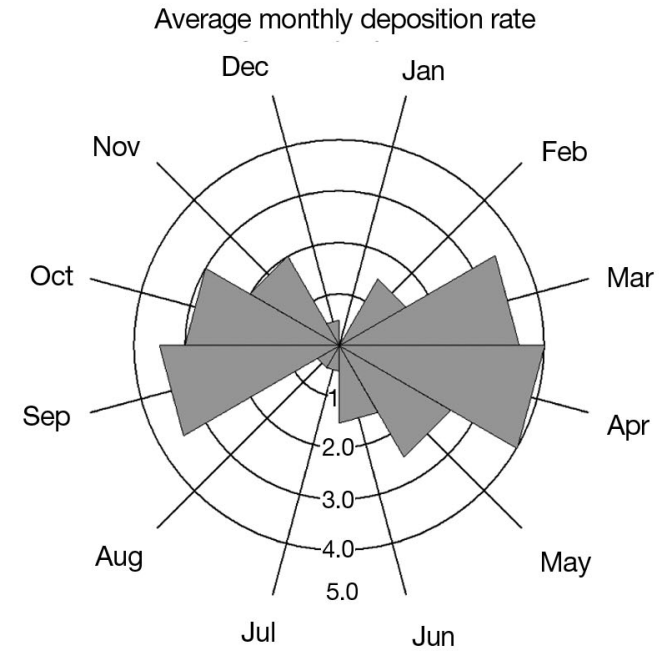

Fig. 5. Average monthly seawater fluorescence (fluorescence units) and average monthly deposition of detritic matter (mm) from August 2007 to July 2008
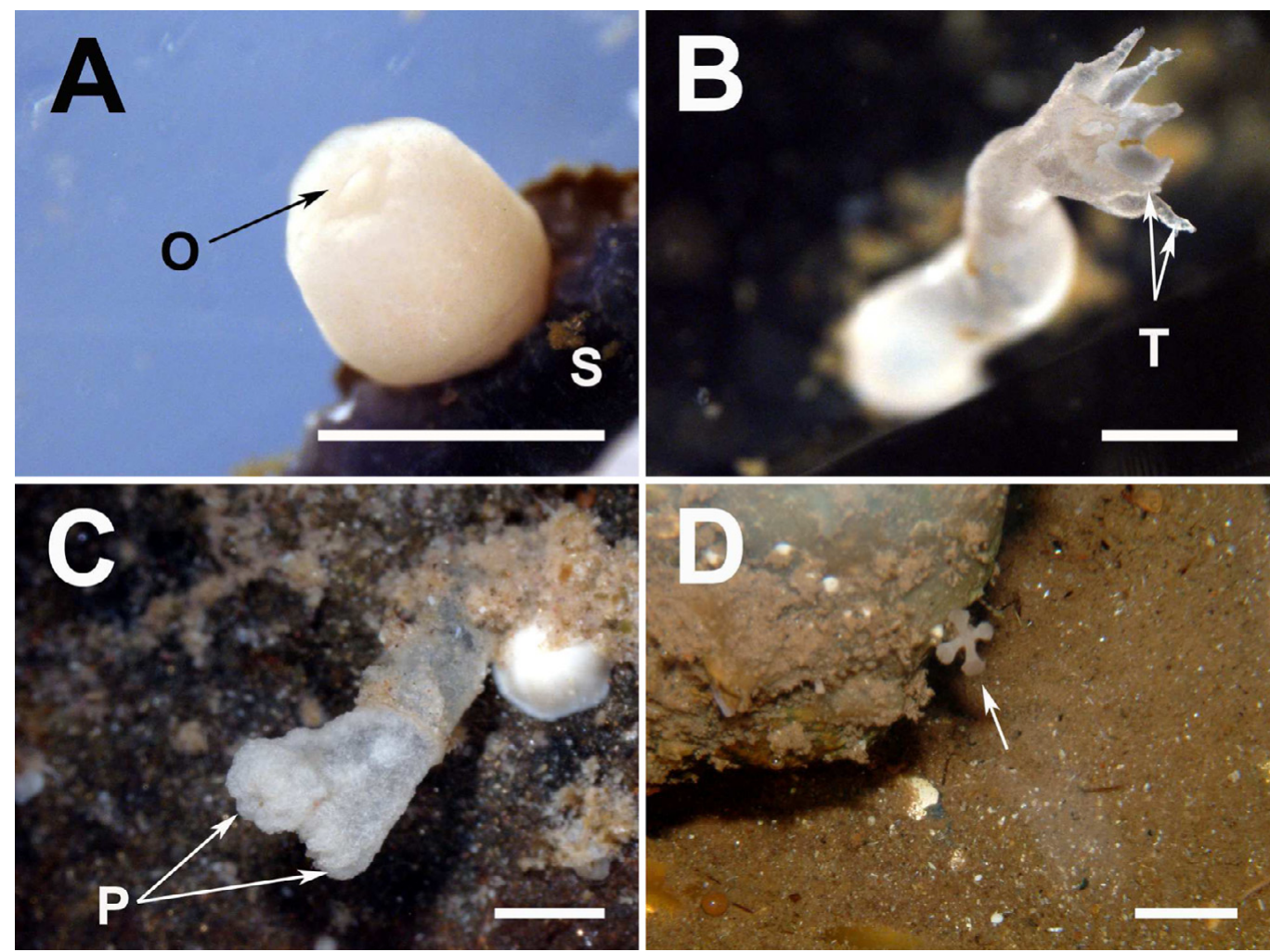

Fig. 6. Drifa sp. Primary polyps photographed in (A) September 2007 and (B) November 2007. (C) Two-polyp colony and (D) 4polyp colony (arrow) found in the holding tank with adults. O: oral pore; S: shell; T: tentacle; P: polyp. Scale bars = (A-C) $1 \mathrm{~mm}$, (D) $3 \mathrm{~mm}$ 


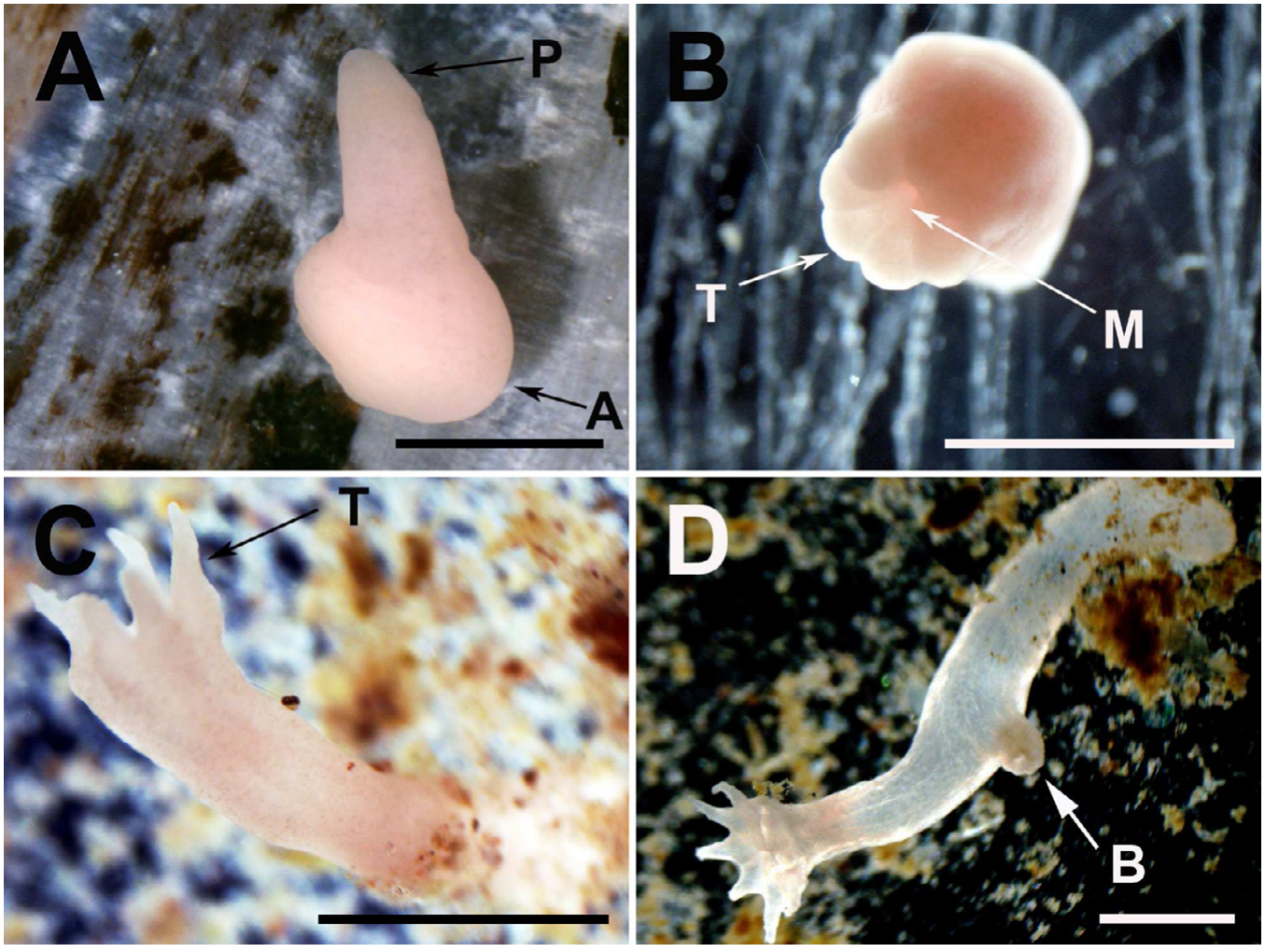

Fig. 7. Drifa glomerata. (A) Newly released planula exploring the substratum. (B) Newly settled primary polyp. (C) Primary polyp after 1 mo of growth in the laboratory. (D) Budding polyp. A: aboral end of planula; P: oral end of planula; T: tentacle; M: mouth; B: budding polyp. Scale bars $=1 \mathrm{~mm}$

as the sequences described in Drifa sp. Planulae became cone-shaped or flattened at settlement (Fig. 7A). The 8 primary mesenteries and primary tentacles typically started to develop within $24 \mathrm{~h}$ post settlement (Fig. 7B), and primary polyps reached their maximum size (ca. 4 to $5 \mathrm{~mm}$ in length and 1 to $2 \mathrm{~mm}$ in stalk diameter) at 2 to 3 mo post settlement. No further growth of primary polyps was observed during the experiment (ca. $12 \mathrm{mo}$ ); however, a budding polyp was observed in the laboratory in March 2009 (ca. 9 mo post release; Fig. 7D).

\section{Settlement preferences}

\section{Drifa sp.}

Naturally released planulae generally settled after 1 to $30 \mathrm{~d}$, although a small portion of larvae took ca. 3 mo to settle. In independent treatments (Fig. 8), planulae of colonies from $1200 \mathrm{~m}$ typically exhibited higher settlement rates $\left(\chi_{1,88}^{2}=28.17, \mathrm{p}<0.05\right)$ and shorter time to settlement $\left(\chi^{2}{ }_{1,138}=39.06, \mathrm{p}<0.05\right)$ than those from $500 \mathrm{~m}$. Furthermore, considering both depths studied, the type of substratum clearly influenced the settlement rates $\left(\chi^{2}{ }_{4,88}=34.34, \mathrm{p}<0.05\right)$ and the time to settlement $\left(\chi_{4,138}^{2}=36.45, \mathrm{p}<0.05\right)$; however, significant interaction indicated that the trends were different $\left(\chi^{2}{ }_{1,138}=39.09, \mathrm{p}<0.05\right)$. In planulae from colonies sampled at both depths, settlement occurred more frequently $\left(\chi^{2}{ }_{1,56}=29.09, \mathrm{p}<0.05\right)$ and faster $\left(\chi_{1,85}^{2}=7.59\right.$, $\mathrm{p}<0.05)$ on hard irregular substrata, such as conditioned shells (NS) than on smooth artificial surfaces (NP) of conditioned culture plates. Planulae also settled more frequently $\left(\chi_{1,45}^{2}=8.74, \mathrm{p}<0.05\right)$ and faster (at $500 \mathrm{~m} \chi_{1,33}^{2}=15.45, \mathrm{p}<0.05$; at $1200 \mathrm{~m} \chi_{1,26}^{2}=6.34$, $\mathrm{p}=0.05$ ) on rough (NPS) than smooth (NP) surfaces. Although planulae tended to settle more frequently on conditioned (NS) than clean (CS) shells at both depths (Fig. 8), no significant differences in settlement rates were detected $\left(\chi_{1,27}^{2}=2.7, p=0.10\right)$. Furthermore, planulae from $500 \mathrm{~m}$ settled faster on clean shells (CS) than conditioned shells $(\mathrm{NS})\left(\chi_{1,35}^{2}=8.78, \mathrm{p}<0.05\right)$, whereas no significant differences were detected in planulae from $1200 \mathrm{~m}\left(\chi_{1,26}^{2}=0.03, \mathrm{p}=0.85\right)$. No significant differences in settlement rates were found between clean (CP) and conditioned (NP) culture plates $\left(\chi_{1,51}^{2}=0.14, p=0.70\right)$. However, planulae from 


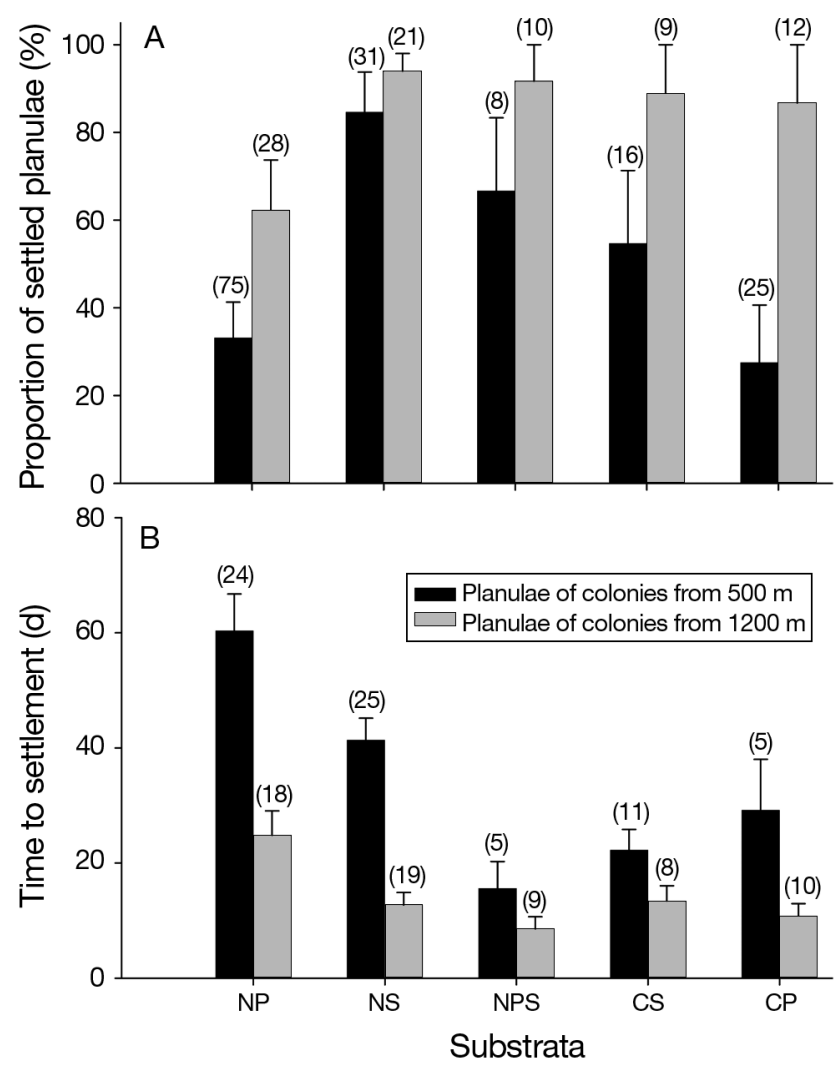

Fig. 8. Drifa sp. (A) Settlement rates and (B) time to settlement on different substrata of planulae emitted by colonies from 500 and $1200 \mathrm{~m}$. NP: conditioned culture plates; NS: conditioned shell fragments; NPS: rough and conditioned culture plate; CS: culture plates with cleaned shell fragments; CP: cleaned culture plates. Data are means \pm SE with total number of planulae tested for each treatment shown in parentheses

both depths settled faster on clean (CP) than conditioned (NP) smooth surfaces $\left(\chi_{1,56}^{2}=10.28, \mathrm{p}<0.05\right)$.

In pair-wise experiments (Fig. 9), planulae of colonies from $500 \mathrm{~m}$ tended to settle more frequently on natural conditioned shells (NS) than conditioned rough Petri dishes (NPS), although no statistical significance was detected $\left(\chi_{1,7}^{2}=1.86, p=0.173\right)$. Similarly, a larger proportion of planulae tended to favour conditioned $(\mathrm{N})$ over clean $(\mathrm{C})$ surfaces, but not statistically so $\left(\chi_{1,15}^{2}=3.24, p=0.072\right)$. More planulae settled on rough (R) than smooth $(\mathrm{S})$ surfaces $\left(\chi_{1,11}^{2}=4.57, \mathrm{p}<\right.$ $0.05)$. Because only 1 planula settled on clean (C) surfaces, no statistical analysis was performed on time to settlement on different substrata.

Surgically extracted planulae settled after 1 to $30 \mathrm{~d}$ (over a single month of monitoring). For each colony, planulae settlement rates varied from 0 to $28.3 \%$. No clear differences in planula behaviour or juvenile growth rates were detected between surgically extracted and naturally released planulae.

\section{Drifa glomerata}

In the pair-wise trials, planulae tended to settle more frequently on conditioned shells (NS, natural substratum) than on conditioned culture plates (NPS, artificial substratum); however, no significant differences were detected $\left(\chi_{1,7}^{2}=2.80, p=0.09\right.$, Fig. 10$)$. A significantly larger proportion of planulae settled on conditioned rough $(\mathrm{R})$ than on conditioned smooth $(\mathrm{S})$ surfaces $\left(\chi_{1,15}^{2}=14.49, \mathrm{p}<0.05\right)$, and on conditioned $(\mathrm{N})$ surfaces than on clean $(C)$ surfaces $\left(\chi^{2}{ }_{1,13}=5.96, p<0.05\right)$.

Larval settlement almost invariably occurred within $1 \mathrm{mo}$ however, a small proportion of larvae partially metamorphosed and remained in the water column for up to 2 mo post release. As in Drifa sp., no statistical analysis could be performed on the time to settlement
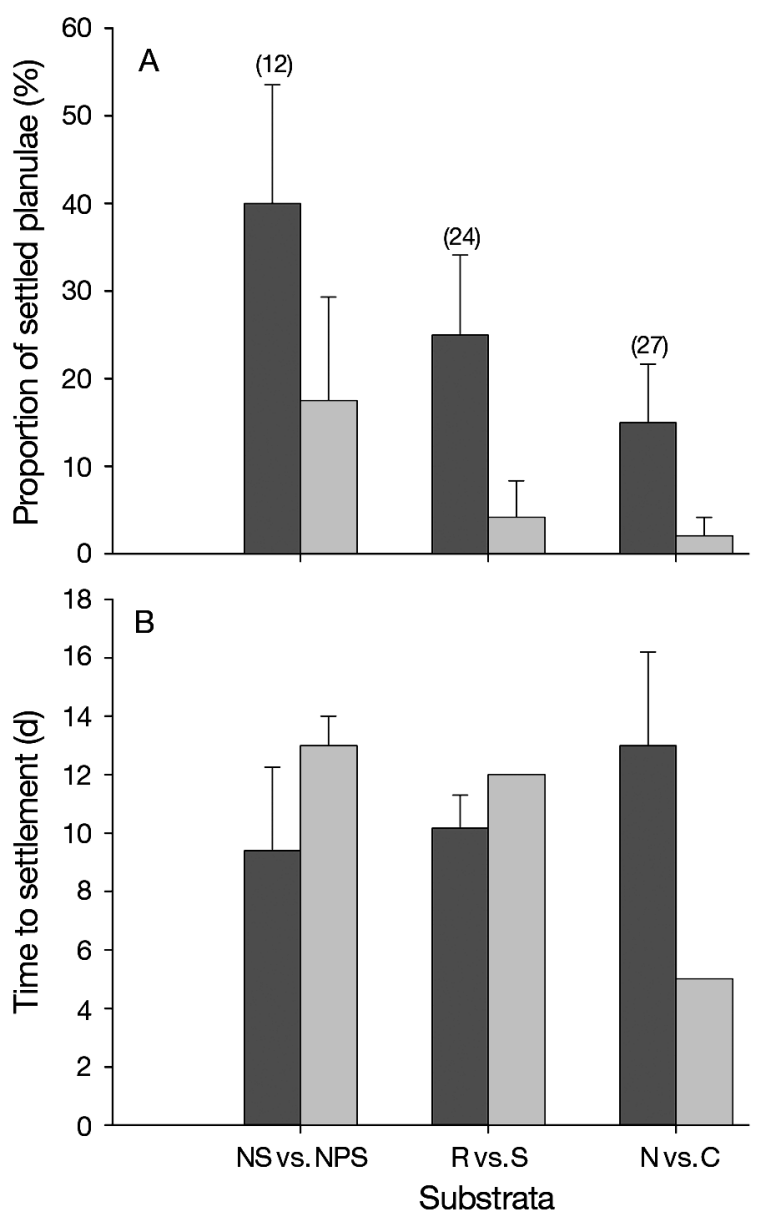

Fig. 9. Drifa sp. (A) Settlement rates and (B) time to settlement on different substrata of planulae emitted by colonies from $1200 \mathrm{~m}$. Data were collected over 1 mo in 3 pair-wise experiments: NS (conditioned shell fragments) versus NPS (rough and conditioned Petri dish), R (rough) versus S (smooth) surface, N (natural) versus C (clean) Petri dish. Data are means \pm SE with total number of planulae tested for each treatment shown in parentheses 

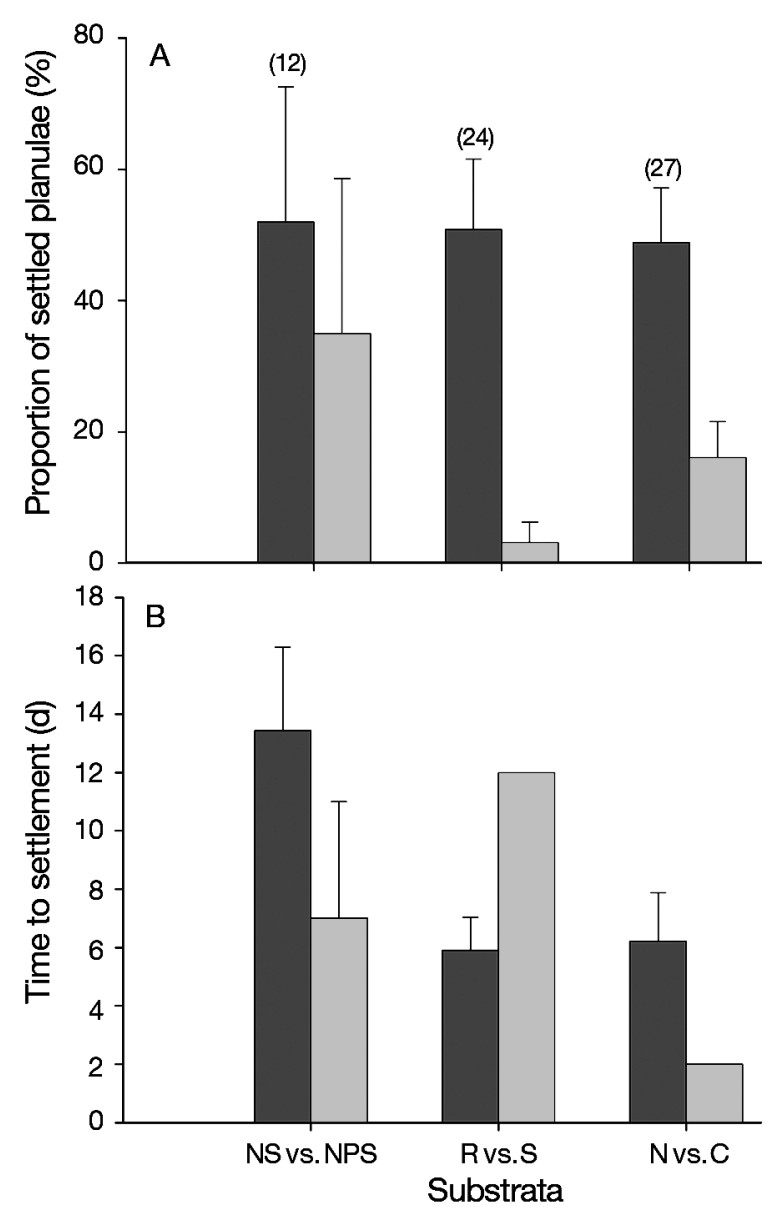

Fig. 10. Drifa glomerata. (A) Settlement rates and (B) time to settlement on different substrata. Data were collected in 3 pair-wise experiments: NS (natural shell fragments) versus NPS (rough and conditioned Petri dish), R (rough) versus S (smooth) surface, N (natural) versus $\mathrm{C}$ (clean) rough Petri dish. Data are means \pm SE with total number of planulae tested for each treatment shown in parentheses

on different substrata because of small sample sizes; i.e. only 1 planula settled on smooth (S) and clean (C) surfaces.

\section{DISCUSSION}

This work provides evidence of correlations between seasonal peaks in the planulation of Drifa sp. and factors such as productivity (concentration of chlorophyll and detritic matter in seawater) and depth distribution. Significant lunar patterns in planula release were also detected. Furthermore, the planulae of both Drifa species showed preference for settlement on rough natural surfaces covered with biofilm, although larvae of colonies from deeper habitats seemed less selective than those originating from shallower habitats. Primary polyps of both Drifa species reached a maximum size ca. 2 to 3 mo after settlement and thereafter exhibited little growth. Behaviour, settlement and post-metamorphic growth of surgically extracted planulae in Drifa sp. were comparable to those of naturally released larvae, suggesting that viable offspring can emerge from tears in fertile colonies (e.g. as an outcome of trawl damage). However, the shortage of preferred settlement substrata and the extremely slow growth of primary polyps emphasize the vulnerability of deep-sea soft coral populations which are not likely to recover easily from depletion due to natural and anthropogenic disturbances.

\section{Reproductive features}

Both Drifa species appear to be female-dominated hermaphrodites with a short oogenesis, rapid embryogenesis and brief spermatogenesis. In Drifa sp. the oocytes and planulae were observed all year long, whereas spermaries were seen only once in 2 colonies. Males of $D$. glomerata were never observed in the live colonies monitored here, nor were they present in serially preserved field samples analysed in a previous study (Sun et al. 2010).

Both Drifa species showed all stages of oocyte and planula development in the same reproductive/feeding polyp with no indication of embryonic development ever recorded, suggesting rapid embryogenesis. A similar conclusion was reached in the study of Xenia macrospiculata (Xeniidae) from the Red Sea (Achituv et al. 1992). The coexistence of all stages of oocytes was also noted in 3 deep-sea scleractinian corals from New Zealand, prompting Burgess \& Babcock (2005) to propose that oocytes were produced at the start of the reproductive season and developed continuously on the basis of the availability of food. In Drifa sp., the important intra-brood and intra-colony differences observed in the size of planulae are consistent with a prolonged rearing period during which the small planulae grow into large elongated planulae before release. A few small planulae (1 to $2 \mathrm{~mm}$ ) were released together with the larger planulae ( 3 to $5 \mathrm{~mm}$ ) in colonies of Drifa sp. from $500 \mathrm{~m}$, and a few even smaller planulae $(<1 \mathrm{~mm})$ were observed on rare occasions. Overall, on the basis of the coexistence of all stages of oocyte development, the absence of embryos and the size differences in planulae, we suggest that rapid embryogenesis and slow maturation of planulae occur on a continuous or semi-continuous basis.

\section{Planulation}

The depth at which the parent colonies of Drifa sp. were collected clearly had an effect on the observed 
breeding season in Drifa sp., in that the planulation period of colonies from $1200 \mathrm{~m}$ was several months shorter than that of colonies from $500 \mathrm{~m}$. Similarly, in an investigation of the shallow-water scleractinian coral Stylophora pistillata (Rinkevich \& Loya 1987), colonies from $5 \mathrm{~m}$ were more fecund than colonies from 24 to $45 \mathrm{~m}$, and their reproductive season was 2 to 3 mo longer. We are aware that the results obtained here must be interpreted with caution, because estimates of planulation duration may be biased by the difference in the size of colonies from the 2 depth ranges. The influence of size on the reproduction of corals has been demonstrated in previous studies (McFadden 1991, Sakai 1998, Kapela \& Lasker 1999, Tsounis et al. 2006).

The brief appearance of spermaries in December 2007 and their total absence in other months suggest that sperm release occurred during that period. Consequently, a large number of oocytes may have been fertilized in December, developed into the first cohort of planulae, and then were released during the peak planulation season between March and May. Subsequently, slower-maturing planulae would be released at irregular intervals. Extended and overlapping oogenic and brooding cycles were reported in the solitary coral Balanophyllia elegans (Fadlallah \& Pearse 1982). The evidence gathered from the fertile colonies of Drifa glomerata and Drifa sp. shows that even at the individual level, planula release can last several weeks or months. One particularly large colony of Drifa sp. intermittently released planulae over $11 \mathrm{mo}$, and the D. glomerata colony produced planulae for ca. 6 mo before dying accidentally. Nonetheless, we saw smaller colonies becoming spent after a limited number of planulation episodes, suggesting a possible relationship between length of planulation period and size of colony.

In Drifa sp. both the occurrences of planulation events and the number of planulae released peaked between September and December in colonies from the 2 depth ranges, whereas only the colonies from $500 \mathrm{~m}$ exhibited a second smaller peak in the spring. Seasonal patterns in planulation have been observed in shallow-water soft corals (Ben-David-Zaslow et al. 1999). As a result of the logistical constraints associated with the study of deep-sea organisms, our study was conducted over a single year, using a relatively small number of colonies. Caution therefore dictates that interpretations related to the timing, intensity and duration of planulation events over the annual cycle be made carefully despite the clear statistical support. Interestingly, the colony of D. glomerata did not release any planulae until January 2008, which corresponded to the onset of the breeding period determined using serial gonad samples of this species in a previous study (Sun et al. 2010). This consistency lends strong support to the laboratory results.

The analysis of the observed seasonal periodicity in planulation can be made from 2 perspectives. Either the colonies followed an internal rhythm set by external stimuli prior to their collection (i.e. we observed only the culmination of a pre-determined reproductive cycle), or the onset of planulation was in direct response to factors occurring in the laboratory environment. The influence of seasonal flux in food availability (i.e. phytodetritus) on reproduction has been documented for several benthic invertebrates (Tyler et al. 1982, Benayahu 1997, Ben-David-Zaslow et al. 1999, Wigham et al. 2003, Mercier \& Hamel 2008, Sun 2009). Moreover, azooxanthellate soft corals are passive suspension feeders known to take advantage of various types of food particles, including zooplankton and phytoplankton (Fabricius et al. 1995). In our study, peak planulation in the fall exhibited a striking coincidence with major increments in chlorophyll concentration and abundance of detritic matter. The second wave of planulation recorded in colonies from $500 \mathrm{~m}$ in the spring again showed the same correlations. These results suggest that a threshold of oceanic productivity is required to stimulate planulation. The greater number of planulae released in the fall could be the result of greater availability of nutrients in the previous months, enhancing the maturation of more planulae compared to spring planulation that followed a period of low productivity. On the other hand, it could be that the fall planulation events were pre-determined prior to collection and that the more fecund colonies from $500 \mathrm{~m}$ were able to undergo a second wave in response to environmental stimuli in the laboratory. Plankton production or resulting marine snow is the more probable planulation inducer in Drifa sp., as suggested for D. glomerata on the basis of a study of field samples (Sun et al. 2010).

Apart from seasonal periodicity, the present study found clear evidence of lunar rhythms in planulation. While the single colony of Drifa glomerata monitored here and the serial samples analyzed previously (Sun et al. 2010) did not provide evidence of lunar periodicity, a strong correlation between planulation and the lunar phase was detected in another deep-sea nephtheid, Gersemia fruticosa, from the same general area (Sun 2009). Moreover, planulation patterns of Drifa sp. colonies from both depths studied were significantly correlated to the moon phases. The more numerous and more intense releases of planulae during the waning moon coincided with a decrease in illumination and an increase in the geomagnetic field. The fact that colonies maintained in our tanks exhibited a lunar periodicity in planulation suggests that they may pos- 
sess an endogenous clock entrained by any of the lunar cues perceptible in the field. Alternatively, few lunar stimuli could act on the tanks, except for the gravitational field. These results are unexpected for deep-sea species; they suggest that the perception of lunar cycles may extend to deep ocean strata, possibly via modulation of tidal currents or hydrostatic pressure. On the other hand, the influence of light (including lunar luminance) cannot be completely discarded, at least for colonies living above the limit of downwelling illumination (ca. 1000 m; Schiebel et al. 2007, Mercier \& Hamel 2008).

\section{Planula behaviour and metamorphosis}

Planulae exhibited distinctive behaviours in the 2 Drifa species. The majority of planulae from D. glomerata were demersal and actively crawled and probed the substratum immediately after their release. However, planulae of Drifa sp. frequently navigated between the water column and the bottom, shifting their position mainly via whole body expansion and contraction. The prevalence of strictly demersal planulae with crawling/searching behaviours will likely enhance local recruitment of new polyps in D. glomerata compared to Drifa sp. The average size of planulae in Drifa sp. was ca. 3 to $4 \mathrm{~mm}$; however, smaller planulae $(\leq 1$ to $2 \mathrm{~mm}$ ) were observed in colonies from $500 \mathrm{~m}$. Those planulae presumably need more time before settlement and suggest dispersal on a larger scale, as stated by Sebens (1983a). However, we did not notice the size differences of planulae until late December 2007, and most of the 1200-m colonies had stopped planulation by that time.

Demersal planulae are believed to settle rapidly and aggregate within the parental habitat (Sebens 1983b, Dunstan \& Johnson 1998). The planulae released by both Drifa species were able to settle within $2 \mathrm{~d}$ or delay settlement for several months, either by prolonging the planula stage or metamorphosing partially in the water column before finally settling. However, some individuals developed into polyps without settling, presumably to initiate feeding and thus enhance dispersal over long distances. This capacity to delay settlement is consistent with field observations of colonies distributed sparsely on mud, which may be the result of protracted pelagic movements before settlement. Generally, in benthic marine invertebrates, metamorphosis is triggered by a permanent attachment to the substratum (Rodriguez et al. 1993); however, metamorphosis before settlement has occasionally been reported (for a review Thorson 1950), for example, in the soft coral Heteroxenia fuscescens (Zaslow \& Benayahu 1996). The ability of planulae to undergo partial metamorphosis is probably linked to the absence of an appropriate settlement cue and is advantageous for increasing the probability of settlement on more suitable substrata (Zaslow \& Benayahu 1996). Alternatively, this behaviour may be triggered as the planula runs out of energy necessary for metamorphosis, in a manner consistent with the 'desperate larva hypothesis' (Gibson 1995, Toonen \& Pawlik 2001).

\section{Settlement preferences}

In both species studied here, pair-wise experiments showed that planulae generally settled faster and more frequently on hard substrata with asperities and a natural biofilm than on all other substrata tested. In the field, colonies of nephtheids were frequently observed in clusters on firm substrata, such as rocks, sponges, shell debris, tube worms, etc., especially at $1200 \mathrm{~m}$, where mud is the dominating substratum. Two nonexclusive explanations are suggested for the local aggregation: (1) planulae are well developed and ready to settle immediately upon release and (2) conspecific adults induce or favour settlement. Considering the rarity of spermaries in Drifa sp. and the virtual absence of males in D. glomerata (Sun et al. 2010), gregariousness could be an adaptation to increase fertilization success in deep-sea octocorals.

Settlement experiments in the laboratory further indicated that planulae of Drifa sp. collected at $1200 \mathrm{~m}$ were more competent to probe substrata and were able to settle more quickly within the appropriate habitat than those of colonies from $500 \mathrm{~m}$. Again, 2 non-exclusive explanations can be offered: (1) planulae released by colonies from $1200 \mathrm{~m}$ require less precise/definite environmental inducers (i.e. they are more opportunistic) and (2) planulae released by colonies from $1200 \mathrm{~m}$ are more developed (i.e. brooded for a longer time inside the colonies until they are ready to settle). The former could be an adaptation to the paucity of hard substrata available at $1200 \mathrm{~m}$ depth as confirmed by the ROV images from the sampling sites, whereas the latter is supported by the fact that only colonies from $500 \mathrm{~m}$ released the tiniest planulae (1 to $2 \mathrm{~mm}$ long).

\section{Growth}

Shallow-water soft corals species are commonly reported to exhibit fast growth and rapid colonization (Harrington et al. 2004). However, primary polyps of the bathyal species studied here exhibited very slow growth rates. Primary polyps virtually stopped grow- 
ing when they reached a certain size (generally after 2 to 3 mo post settlement). Furthermore, no budding of primary polyps of Drifa sp. was observed over the course of the monitoring (i.e. 21 mo post settlement for the older polyps), although a 2-polyp colony and a 4-polyp colony were discovered in the unmonitored tank holding adults. A single budding polyp of $D$. glomerata was observed ca. 9 mo post release among the monitored experimental specimens. These observations lead to 2 main hypotheses. (1) Environmental factors in the laboratory might adversely influence growth rates. Although seawater temperatures and food availability were maintained within a range that was appropriate for deep-sea corals, the pressure level was different. The influence of pressure on the reproduction and growth of deep-sea invertebrates appears to be minimal on the basis of previous studies of corals and echinoderms (Mercier \& Hamel 2008, Sun et al. 2009, Hamel et al. 2010), whereas larvae of many species have been shown to tolerate large pressure changes (Pradillon \& Gaill 2007). (2) Alternatively, early growth rates of primary polyps are extremely slow, as inferred by the few other experimental growth studies that have been conducted on post-settled corals. For example, no budding of the shallow-water temperate soft coral Dendronephthya gigantean (Nephtheidae) was recorded during a 1 mo study (Hwang \& Song 2007). In the deep-sea alcyonacean coral Anthomastus ritteri, juvenile colonies developed a second autozooid after 1 to 2 mo and displayed very slow growth in the first 8 to 9 mo (Cordes et al. 2001). Even though growth was slow in the 2 deep-sea Drifa species studied here and in 2 other sympatric deep-sea nephtheids studied previously (Sun 2009), it may be compensated by a relatively precocious sexual maturity, as shown by the presence of planulae in small colonies composed of only 10 to 25 polyps.

Acknowledgements. We gratefully acknowledge the support of Fisheries and Oceans Canada (especially K. Gilkinson, Science Branch) and of the Natural Sciences and Engineering Research Council of Canada and Canada Foundation for Innovation (grants to A.M.). We also thank various people for assistance at different stages of this study: E. Edinger, P. Snelgrove, V. Wareham, O. Sherwood, crew and staff of CCGS 'Hudson' and CCGS 'Teleost', ROPOS team, DFO/BIO staff and scientists on board the 'Hudson' (with special thanks to E. Kenchington, K. MacIsaac, and B. Macdonald), C. Short, D. Schneider, D. Ings, K. William, J. Foote, A. Taylor, M. Rise, J. So, G. Doyle, C. Negrijn, L. Combdon, OSC Laboratory and Field Services, live feed technicians and C. McFadden from Harvey Mudd College for the identification of corals. This research was carried out in partial fulfillment of the requirements for Master of Science degree at Memorial University (Z.S.).

\section{LITERATURE CITED}

Abelson A (1997) Settlement in flow: upstream exploration of substrata by weakly swimming larvae. Ecology 78: $160-166$

Achituv Y, Benayahu Y, Hanania J (1992) Planulae brooding and acquisition of zooxanthellae in Xenia macrospiculata (Cnidaria: Octocorallia). Helgol Mar Res 46:301-310

Atoda K (1951) The larva and postlarval development of the reef-building corals IV. Galaxea aspera Quelch. J Morphol 89:17-35

Ayre DJ, Miller KJ (2004) Where do clonal coral larvae go? Adult genotypic diversity conflicts with reproductive effort in the brooding coral Pocillopora damicornis. Mar Ecol Prog Ser 277:95-105

> Baird AH, Babcock RC, Mundy CP (2003) Habitat selection by larvae influences the depth distribution of six common coral species. Mar Ecol Prog Ser 252:289-293

Ben-David-Zaslow R, Henning G, Hofmann DK, Benayahu Y (1999) Reproduction in the Red Sea soft coral Heteroxenia fuscescens: seasonality and long-term record (1991 to 1997). Mar Biol 133:553-559

- Benayahu Y (1991) Reproduction and developmental pathways of Red Sea Xeniidae (Octocorallia, Alcyonacea). Hydrobiologia 216-217:125-130

Benayahu Y (1997) Developmental episodes in reef soft corals: ecological and cellular determinants. In: Lessios HA, MacIntyre IG (eds) Proc 8th Int Coral Reef Symp, Smithsonian Tropical Research Institute, Balboa, Panama, p 1213-1218

Benayahu Y, Loya Y (1983) Surface brooding in the Red Sea soft coral Parerythropodium fulvum fulvum (Forskal, 1775). Biol Bull (Woods Hole) 165:353-369

Benayahu Y, Loya Y (1984) Life history studies on the Red Sea soft coral Xenia macrospiculata Gohar, 1940. II. Planulae shedding and post larval development. Biol Bull (Woods Hole) 166:44-53

Benayahu Y, Weil D, Malik Z (1992) Entry of algal symbionts into oocytes of the coral Litophyton arboreum. Tissue Cell 24:473-482

Buhl-Mortensen L, Mortensen PB (2005) Distribution and diversity of species associated with deep-sea gorgonian corals off Atlantic Canada. In: Freiwald A, Roberts JM (eds) Cold-water corals and ecosystems. Springer Verlag, Berlin, p 849-879

Burgess SN, Babcock RC (2005) Reproductive ecology of three reef-forming, deep-sea corals in the New Zealand region. In: Freiwald A, Roberts JM (eds) Cold-water corals and ecosystems. Springer Verlag, Berlin, p 701-713

> Cordes EE, Nybakken JW, VanDykhuizen G (2001) Reproduction and growth of Anthomastus ritteri (Octocorallia: Alcyonacea) from Monterey Bay, California, USA. Mar Biol 138:491-501

Costello MJ, McCrea M, Freiwald A, Lundälv T and others (2005) Role of cold-water Lophelia pertusa coral reefs as fish habitat in the NE Atlantic. In: Freiwald A, Roberts JM (eds) Cold-water corals and ecosystems. Springer Verlag, Berlin, p 771-805

> Dahan M, Benayahu Y (1997) Reproduction of Dendronephthya hemprichi (Cnidaria: Octocorallia): year-round spawning in an azooxanthellate soft coral. Mar Biol 129: 573-579

> DeBruyn AMH, Meeuwig JJ (2001) Detecting lunar cycles in marine ecology: periodic regression versus categorical ANOVA. Mar Ecol Prog Ser 214:307-310

> Dunstan PK, Johnson CR (1998) Spatio-temporal variation in coral recruitment at different scales on Heron Reef, south- 
ern Great Barrier Reef. Coral Reefs 17:71-81

Eckelbarger KJ, Tyler PA, Langton RW (1998) Gonadal morphology and gametogenesis in the sea pen Pennatula aculeata (Anthozoa: Pennatulacea) from the Gulf of Maine. Mar Biol 132:677-690

Fabricius KE (1997) Soft coral abundance on the central Great Barrier Reef: effects of Acanthaster planci, space availability, and aspects of the physical environment. Coral Reefs 16:159-167

Fabricius KE, Genin A, Benayahu Y (1995) Flow-dependent herbivory and growth in zooxanthellae-free soft corals. Limnol Oceanogr 40:1290-1301

Fadlallah YH, Pearse JS (1982) Sexual reproduction in solitary corals: overlapping oogenic and brooding cycles, and benthic planulas in Balanophyllia elegans. Mar Biol 71: 223-231

Farrant PA (1986) Gonad development and the planulae of the temperate Australian soft coral Capnella gaboensis. Mar Biol 92:381-392

Flint HC, Waller RG, Tyler PA (2007) Reproductive ecology of Fungiacyathus marenzelleri from $4100 \mathrm{~m}$ depth in the northeast Pacific Ocean. Mar Biol 151:843-849

Freiwald A, Fosså JH, Grehan A, Koslow T, Roberts JM (2004) Cold-water coral reefs. UNEP-WCMC Biodiversity Series No. 22, United National Environment Programme, World Conservation Monitoring Centre, Cambridge, p 1-84

Gibson G (1995) Why be choosy? Temporal changes in larval sensitivity to several naturally-occurring metamorphic inducers in the opisthobranch Haminaea callidegenita. J Exp Mar Biol Ecol 194:9-24

Glassom D, Celliers L, Schleyer MH (2006) Coral recruitment patterns at Sodwana Bay, South Africa. Coral Reefs 25: 485-492

Gotceitas V, Methven DA, Fraser S, Brown JA (1999) Effects of body size and food ration on over-winter survival and growth of age-0 Atlantic cod, Gadus morhua. Environ Biol Fishes 54:413-420

Hamel JF, Sun Z, Mercier A (2010) Influence of size and seasonal factors on the growth of the deep-sea coral Flabellum alabastrum in mesocosm. Coral Reefs 29:521-525

> Harrington L, Fabricius K, De'ath G, Negri A (2004) Recognition and selection of settlement substrata determine postsettlement survival in corals. Ecology 85:3428-3437

Harrison PL, Wallace CC (1990) Reproduction, dispersal and recruitment of scleractinian corals. In: Dubinsky Z (ed) Ecosystems of the world: Vol 25, coral reefs. Elsevier Science Publishers, Amsterdam, p 133-207

> Heyward AJ, Negri AP (1999) Natural inducers for coral larval metamorphosis. Coral Reefs 18:273-279

Hodgson G (1985) Abundance and distribution of planktonic coral larvae in Kaneohe Bay, Oahu, Hawaii. Mar Ecol Prog Ser 26:61-71

> Hwang SJ, Song JI (2007) Reproductive biology and larval development of the temperate soft coral Dendronephthya gigantea (Alcyonacea: Nephtheidae). Mar Biol 152:273-284

Jokiel PL, Guinther EB (1978) Effects of temperature on reproduction in the hermatypic coral Pocillopora damicornis. Bull Mar Sci 28:786-789

Kapela W, Lasker HR (1999) Size-dependent reproduction in the Caribbean gorgonian Pseudoplexaura porosa. Mar Biol 135:107-114

McCullagh P, Nelder JA (1989) Generalized linear models. Chapman \& Hall, London

> McFadden CS (1991) A comparative demographic analysis of clonal reproduction in a temperate soft coral. Ecology 72 : 1849-1866

Mercier A, Hamel JF (2008) Depth-related shift in life history strategies of a brooding and broadcasting deep-sea asteroid. Mar Biol 156:205-223

Miller K, Neil H, Tracey D (2009) Recent advances in deepsea coral science and emerging links to conservation and management of deep-sea ecosystems. Mar Ecol Prog Ser 397:1-5

Petrie B, Akenhead SA, Lazier SA, Loder J (1988) The cold intermediate layer on the Labrador and Northeast Newfoundland Shelves, 1978-86. Northwest Atl Fish Organ Sci Counc Stud 12:57-69

> Pires DO, Castro CB, Silva JC (2009) Reproductive biology of the deep-sea pennatulacean Anthoptilum murrayi (Cnidaria, Octocorallia). Mar Ecol Prog Ser 397:103-112

- Pradillon F, Gaill F (2007) Pressure and life: some biological strategies. Rev Environ Sci Biotechnol 6:181-195

- Richmond RH (1987) Energetics, competency, and long-distance dispersal of planula larvae of the coral Pocillopora damicornis. Mar Biol 93:527-533

Richmond RH, Hunter CL (1990) Reproduction and recruitment of corals: comparisons among the Caribbean, the Tropical Pacific, and the Red Sea. Mar Ecol Prog Ser 60: 185-203

Rinkevich B, Loya Y (1987) Variability in the pattern of sexual reproduction of the coral Stylophora pistillata at Eilat, Red Sea: a long-term study. Biol Bull (Woods Hole) 173: 335-344

Roberts JM, Wheeler AJ, Freiwald A (2006) Reefs of the deep: the biology and geology of cold-water coral ecosystems. Science 312:543-547

Rodriguez SR, Ojeda FP, Inestrosa NC (1993) Settlement of benthic marine invertebrates. Mar Ecol Prog Ser 97: 193-207

Rogers CS (1990) Responses of coral reefs and reef organisms to sedimentation. Mar Ecol Prog Ser 62:185-202

Sakai K (1998) Effect of colony size, polyp size, and budding mode on egg production in a colonial coral. Biol Bull (Woods Hole) 195:319-325

SAS (1988) SAS/STAT release 6.03., SAS Institute, Cary, NC Schiebel R, Barker S, Lendt R, Thomas H, Bollmann J (2007) Planktic foraminiferal dissolution in the twilight zone. Deep-Sea Res II 54:676-686

Sebens KP (1983a) The larval and juvenile ecology of the temperate octocoral Alcyonium siderium Verrill. 1. Substratum selection by benthic larvae. J Exp Mar Biol Ecol 71: 73-89

> Sebens KP (1983b) The larval and juvenile ecology of the temperate octocoral Alcyonium siderium Verrill. 2. Fecundity, survival, and juvenile growth. J Exp Mar Biol Ecol 72: 263-285

Shlesinger Y, Goulet TL, Loya Y (1998) Reproductive patterns of scleractinian corals in the northern Red Sea. Mar Biol 132:691-701

Stein M (2007) Oceanography of the Flemish Cap and adjacent waters. J Northwest Atl Fish Sci 37:135-146

> Stimson JS (1978) Mode and timing of reproduction in some common hermatypic corals of Hawaii and Enewetak. Mar Biol 48:173-184

Sun Z (2009) Reproductive biology of deep-sea soft corals in the Newfoundland and Labrador region. Master thesis, Memorial University, St. John's

> Sun Z, Hamel JF, Mercier A (2009) Planulation of deep-sea octocorals in the NW Atlantic. Coral Reefs 28:781

> Sun Z, Hamel JF, Edinger E, Mercier A (2010) Reproductive biology of the deep-sea octocoral Drifa glomerata in the Northwest Atlantic. Mar Biol 157:863-873

> Thorson G (1950) Reproductive and larval ecology of marine bottom invertebrates. Biol Rev Camb Philos Soc 25:1-45 
Toonen RJ, Pawlik JR (2001) Settlement of the gregarious tube worm Hydroides dianthus (Polychaeta: Serpulidae). II. Testing the desperate larva hypothesis. Mar Ecol Prog Ser 224:115-131

Tsounis G, Rossi S, Aranguren M, Gili JM, Arntz W (2006) Effects of spatial variability and colony size on the reproductive output and gonadal development cycle of the Mediterranean red coral (Corallium rubrum L.). Mar Biol 148:513-527

Tyler PA, Grant A, Pain SL, Gage JD (1982) Is annual reproduction in deep-sea echinoderms a response to variability in their environment? Nature 300:747-750

Waller RG (2005) Deep-water Scleractinia (Cnidaria: Anthozoa): current knowledge of reproductive processes. In: Freiwald A, Roberts JM (eds) Cold-water corals and ecosystems. Springer Verlag, Berlin, p 691-700

Waller RG, Tyler PA (2005) The reproductive biology of two deep-water, reef-building scleractinians from the NE Atlantic Ocean. Coral Reefs 24:514-522

Editorial responsibility: Hans Heinrich Janssen, Oldendorf/Luhe, Germany
Waller RG, Tyler PA, Gage JD (2005) Sexual reproduction in three hermaphroditic deep-sea Caryophyllia species (Anthozoa: Scleractinia) from the NE Atlantic Ocean. Coral Reefs 24:594-602

Waller RG, Tyler PA, Smith CR (2008) Fecundity and embryo development of three Antarctic deep-water scleractinians: Flabellum thouarsii, F. curvatum and F. impensum. DeepSea Res II 55:2527-2534

Watling L, Auster PJ (2005) Distribution of deep-water Alcyonacea off the Northeast Coast of the United States. In: Freiwald A, Roberts JM (eds) Cold-water corals and ecosystems. Springer Verlag, Berlin, p 259-264

Wigham BD, Tyler PA, Billett DSM (2003) Reproductive biology of the abyssal holothurian Amperima rosea: an opportunistic response to variable flux of surface derived organic matter? J Mar Biol Assoc UK 83:175-188

Zaslow RBD, Benayahu Y (1996) Longevity, competence and energetic content in planulae of the soft coral Heteroxenia fuscescens. J Exp Mar Biol Ecol 206:55-68

Submitted: February 5, 2010; Accepted: April 23, 2010

Proofs received from author(s): June 30, 2010 